\title{
Evaluation of Happy City Indicators in Affordable Housing Projects, Case Study: Mehr Housing Projects, Aftab Town, The City of Parand, Tehran, Iran
}

\author{
Seyed Sajjad Abdollahpour ${ }^{1 *}$, Ehsan Sharifi ${ }^{2}$, and Reza Ghazi ${ }^{3}$ \\ 1 Faculty of Urban Planning and Architecture, University of Art Tehran \\ 2 School of Architecture and Built Environment, University of Adelaide \\ 3 Faculty of Fine Art, University of Tehran \\ *Corresponding Author, Sajad.abdullahpour@gmail.com
}

Received: Feb 11, 2020 Accepted: June 30, 2021

Key words: Design \& Decision Support Systems, Conference, Paper-formatting instructions

\begin{abstract}
The aim of this study is to identify and evaluate the indicators of the happy city in affordable housing projects. The Aftab town in Tehran, Iran, has been chosen as a case study. The research method of this study is descriptiveanalytic. To collect the research data, the field survey method (including the completion of household questionnaires) has been used. T-tests, factor analysis and multivariable regression, were applied in SPSS-22 software for data analysis. The results showed that the status of indicators of a happy city in the Mehr Housing project of Aftab town of Parand is not favourable. Furthermore, the identified indicators of the happy city, respectively, have a priority effect on the happiness of the inhabitants, including the sense of happiness regarding physical and spatial interactions, the local government's support of local residents, the quality of the business environment, the quality of local services, the quality of the artificial and natural environment, the sense of happiness as a result of social and work relationships. According to the results, the most important indicator on the level of happiness for residents in the Mehr housing projects in Parand city is the physical and spatial interactions.
\end{abstract}

\section{INTRODUCTION}

Happiness might be one of the most important pillars of life for the people of a community, which has always been discussed from time to time (Delle Fave, 2013; Ng, 2008; Tiwari and Mutascu, 2015). Contemporary cities, especially those within metropolitan areas, face many environmental, social and aesthetical issues, which lead to a decline in the quality of urban life and happiness for individuals. Accordingly, one of the main challenges facing sustainable urban areas is to provide suitable living conditions in cities (Hall and Pfeiffer, 2000). Since the quality of the built environment affects the human being, this quality is intrinsically linked with the feeling of happiness among people (Kellert and Wilson, 1993; Majeed and Mumtaz, 2017). Hence, increasing the quality of happiness in society will improve the social health of citizens and, in general, improve the quality of life. Therefore, the necessity of strengthening vitality in urban environments is 
considered as one of the most important paradigms in the field of Urban Planning and Design (Pakzad, 2009).

In Iran, like most developing countries, in particular in recent years, access to appropriate residential environments with respect to population growth, land shortages and increased construction and living costs has become an important challenge for Urban Managers (Vuluku and Gachanja, 2014). Countries in which the housing standards and facilities for providing fundamental living conditions are adequate and appropriate, consideration of qualitative debates such as the lively residential environment, the quality of construction, the focus on identity, the provision of quality facilities and facilities are crucial for providing housing projects (Suhaida et al., 2010; Thalmann, 2003). Affordable housing and Public housing projects are kindes of housing that are considered in the agenda of Urban Planners, directors and governments in most countries around the world (Atlas and Dreier, 1992; Bauman, 1987; the United States, 1937; Yan et al., 2014).

In the constitution of Iran, the need for housing has been emphasized for every individual and family. According to that, the provision of housing is a right of every individual and Iranian families, and the government is obliged to give priority to those who are in need. In order to meet the demand for housing in the community, the Mehr Housing Project has become one of the main development projects of the country in recent years by the ninth government in the fourth development plan (Isalou et al., 2015). In the Mehr Housing Project, which was based on policies such as free land provision and support for production and construction (Hemati, 2006), it seems that less attention has been paid to the qualitative factors of residential environments. Nowadays, by passing through Mehr housing projects, these urban areas show the distressed places where people would not be able to communicate with each other in appropriate public spaces.

Addressing happiness, which might be one of the main pillars of improving quality of life, can be a step towards improving the quality of these projects and reducing depression and stress among citizens (Ballas and Dorling, 2013; Bókony et al., 2012; Mirzan et al., 2016; Shochat et al., 2006). It is also a step towards making sustainable places in Mehr housing projects. According to the implementation plan of housing supply programs in 2007, the priority of supplying Mehr housing projects in metropolitan areas is anticipated in new cities. The new town of Parand is one of the five newly built cities in the Tehran metropolis, which is intended to reside as part of Tehran's metropolis. Due to its privileged position, the city of Parand has played a greater role in the Mehr housing assignment programs. According to the 2016 census, it has the highest population growth among the cities of Iran, and today it is named as the capital of Iran's Mehr housing projects. Therefore, the necessity of identifying the indicators affecting happiness and measuring them in the Mehr Housing project in the city of Parand is quite important, considering its status in Mehr housing projects. The present study was carried out with the aim of identifying, explaining and measuring the indicators of the happy city in Iran's Mehr housing projects, which were measured in the Aftab town of Parand city. Therefore, the main questions of the present study are: what is the status of indicators of a happy city in the Mehr housing project of Aftab Town in Parand city? What indicators allow the Mehr housing project of Aftab town to be a model of a happy city? What are the variables that affect the feeling of happiness among inhabitants in Aftab town? In order to follow the aim of this paper and to answer the research questions, firstly, the literature on happiness and the happy city would be reviewed, then, a summary of related work would be 
presented. And, finally, by collecting the data, the evaluation of happy city indicators would be considered.

\section{RESEARCH BACKGROUND}

Joy and happiness have always been discussed throughout history (Athota, 2013). Reviewing and evaluating how the environment in which a person lives, affects the overall sense of life and life satisfaction, for a long time, as an important topic in human geography, urban and regional studies (Ballas, 2013). Happiness in the community encompasses a wide range of economic, social, environmental, cultural, and governance indicators, and people's priorities have been identified as one of the most important one (Musa et al., 2018).

Given the importance of the concept of happiness, it can be said that there has not been much research done in the area of Urban Planning. One of the researches in this area, which was actually trying to identify the elements of a happy city, is related to Balzse's article. Ballas (2013) focuses on happiness and quality of life in cities. This article reviews the studies on happiness and quality of life in the Urban Planning scope and seeks to address the underlying issues and discussions on how to measure and analyze the concept of quality of life and happiness on the city scale. It also highlights the key factors in the quality of life and well-being, with emphasis on spatial justice in geographic, economic, and social fields.

In a general perspective, studies on happiness can be categorized into three broad categories: the relationship between the concepts of social factors and happiness (Amorim et al., 2017; Argyle and Lu, 1990; Balogun, 2014; Coles et al., 2015; Diener and Seligman, 2004; Gu et al., 2017; King et al., 2014; Welsch and Kuhling, 2016), the relationship between the economy and happiness in society (Ferrer-i-Carbonell and Gowdy, 2007; Frey and Stutzer, 2002; Morawetz et al., 1977; Welsch, 2009; Welsch and Kuhling, 2009)and the assessment of environmental concepts related to happiness, (Ballas and Dorling, 2007; Ferreira and Moro, 2010; Kent et al., 2017; Lenzen and Cummins, 2013; Majeed and Mumtaz, 2017; Rehdanz and Maddison, 2005; Tiwari, 2011; Welsch, 2006).

Examples are provided regarding each of the categories that were mentioned above. A major study of joy and happiness can be found in the relationship between happiness and social dimensions. The article by Vinson and Ericson (2014) examines many social variables in relation to happiness, such as marriage status, education, demographic characteristics, citizenship rights, etc. Using statistical methods, they separate the shared variables between happiness and life satisfaction in a way. The study seeks to shape social policies in the Australian community by identifying the main causes of happiness. (Alesina et al., 2001), in a paper using field survey and questionnaire research, evaluated the relationship between happiness and inequality in European and American societies. Their analysis showed that there is a link between inequality and happiness at the community level. In fact, the results indicate a very strong connection and a negative impact of inequality on the vitality and happiness of the community. The results of this study also sought to identify the most important needs of the community in order to help statesmen fight the social inequalities (Hsu and Chang, 2015). In the following article, the relationship between social interactions and happiness was assessed among the ageing population group in Taiwan. The variables of social interaction were considered as the relationship with 
children, parents, friends, relatives, phone calls, emotional support and social partnerships. The results of the research showed that social participation and emotional support are related to happiness, and the quality of social interactions and experiences is more important than the amount of social communication among the elderlies. Many researchers believe that the economic indicators can be one of the main and influential factors on the level of happiness and well-being of individuals. Gudmundsdottir (2013) addresses the connection between economic crisis and the happiness of the people of the community. The purpose of this paper was to examine how economic downturn affects the happiness that this economic crisis faces with lower income, rising unemployment. The relationship between economic factors and happiness was identified using multivariate regression analysis. The results showed that earnings and unemployment are not effective on happiness, but financial problems will affect the sense of happiness. Generally, it can be said that the economic crisis, although limited, has had an effect on happiness, but financial problems have a great effect on the happiness of communities. Habibzadeh and Allahvirdiyani (2011) evaluate the impact of economic and non-economic indicators on the happiness of a group of teachers and university professors. The results showed that the status of marriage, the level of literacy and income did not have a significant effect on the happiness of individuals, but there was a relationship between job security, job satisfaction, the proportion of cost and income, the number of domestic and foreign trips and the age of people with happiness. The paper (Abounoori and Asgarizadeh, 2013) examines the great economic indicators of joy. This essentially sought to answer the question of how much of your whole life you feel joy and happiness. The results showed that unemployment and inflation rates have a negative effect on happiness, and the growth of GDP per capita and the growth of government investment have a positive impact on the happiness of the people.

Apart from the relationship among economic, social indicators and happiness, the environment also plays an important and significant role in the review of happiness literature. A study (Ulrich, 1984) in Pennsylvania during the period between 1972 to 1981 showed that patients treated in rooms with views of trees and nature were more likely to be cured than those who were in rooms without such views. One of the works done in this area is that of Brereton et al. (2008). In his article, Brenton tries to show the relationship between environmental variables with happiness. He believes that although personal variables are important in happiness, paying attention to the passion of the place, such as good weather, a healthy environment, and proper physical conditions in the analysis of the concept of happiness and the welfare of life have an irrefutable role. The spatial surveys show that there is a relationship between environmental criteria and happiness. For example, the results of this study showed that people living near large stations and traffic jams, due to noise pollution, have a lower level of satisfaction with life, or those who live near the beach, feel happier with their lives (Welsch, 2006). Another article explores the relationship between happiness and prosperity with pollution in ten European cities. The results of this paper show that air pollution plays an important and significant role in creating the difference between countries in terms of prosperity and happiness. The paper (White et al., 2013) points out that living alongside urban green spaces such as parks, reduces the stress and pressure of urban living. The results of the study showed that on average, those who had less stress and emotional pressure, as well as a sense of happiness and 
satisfaction, living in areas of the city where the amount of green space in the city was higher.

All in all, reviewing the studies show that while the relationship between happiness and the social, economic and environmental indicators of the built environment has been addressed, all aspects of the happy city and its indicators as a comprehensive concept have been neglected in the scope of Urban Planning. This is an important point that has not been specifically addressed in Iranian cities in general and in the Affordable housing projects particularly. As previously mentioned, this study seeks to identify and evaluate the indicators of the happy city in the Mehr Housing Project in the Aftab town. Therefore, according to the studies conducted in the previous researches, the indicators of the happy city are presented in Table 1, to be considered in the evaluation of the case study.

Table 1. The indicators of a happy city

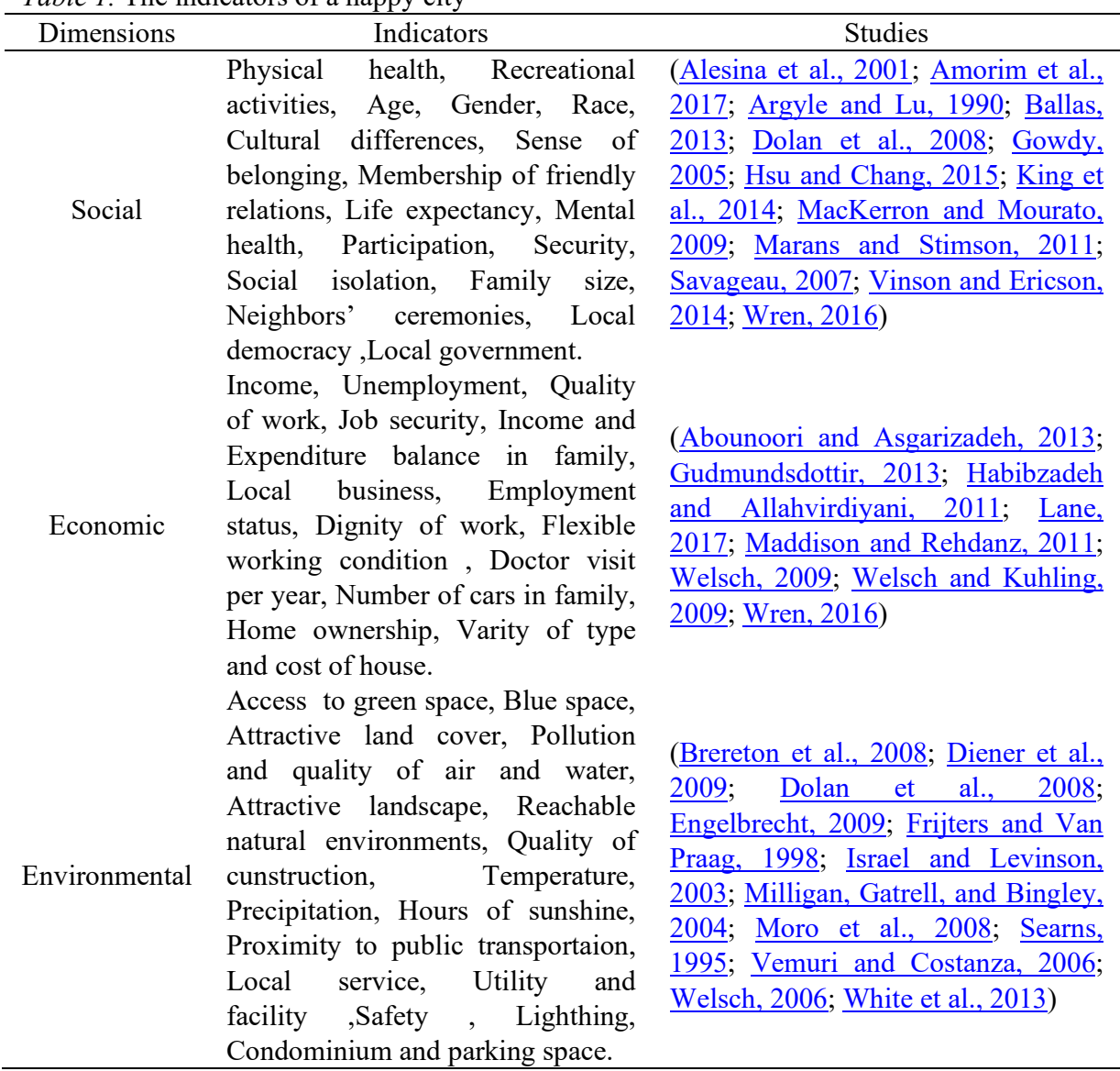

\section{LITERATURE REVIEW}

\subsection{Happiness and happy city}

Sustainable development, which today is one of the main topics discussed by Urban Planners, has a strong relationship with the feeling of happiness (Rafieian et al., 2018; Tanguay et al., 2009; Turkoglu, 2015). Zidansek states that while the greatest share of happiness depends on genetic factors, individual situations and activities are also very important. He states 
that there is a relatively strong correlation between happiness and sustainability, in which happy citizens are more inclined to support sustainable development and are more effective in such efforts. On the other hand, the valuation of quality of life and happiness in cities is synonymous with the concept of sustainability, as bringing these two concepts together is an opportunity to share the concept of "sustainable happiness" in all areas of the urban system (Zidanšek, 2007).

Furthermore, the concept of quality of life, which is one of the most important indicators of urban social sustainability (Akhundi et al., 2014), is another concept that might be close to happiness. Some have interpreted it as the concept of livability; others have been interpreted quality of life as measures of attractiveness, and some others explained this note as general welfare, social well-being, happiness and vitality, satisfaction, etc. (Epley and Menon, 2008). Quality of life has a variety of dimensions, such as social and psychological. Psychological areas include indicators such as satisfaction, happiness, vitality and security (Danaei et al., 2016). Joy and happiness are among the most important psychological indicators of quality of life, and human beings have always sought to achieve peace, prosperity, joy and happiness in their lives (Buss, 2000). It can be said that in most societies, the pleasure and happiness of life are primary goals (Diener et al., 2003). For example, in European-American culture, happiness is considered a positive state of mind, conditioned on personal achievements and maximizing positive human qualities (Myers and Diener, 1995; Uchida and Ogihara, 2012).

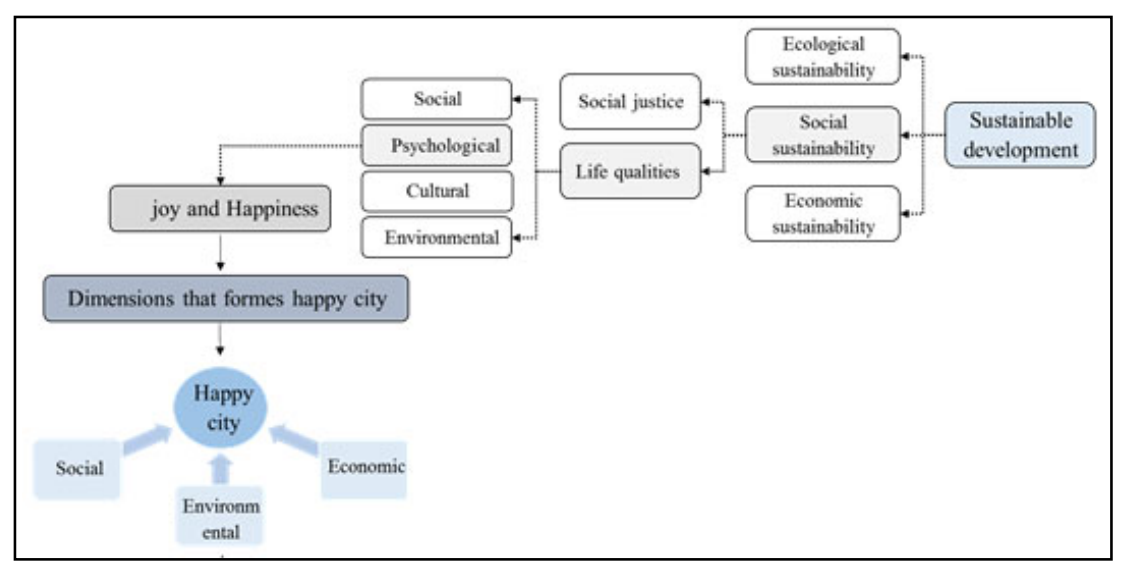

Figure 1. Conceptual model of the research

As for happiness, Frey (2008) makes happiness a product of a fit life that results from long-term satisfaction with life. It can also be said that the sense of happiness is a multidimensional indicator of an unconscious, cognitive, and motivational process that is unique and spatial in how people interpret and judge life (Anic and Toncic, 2013; Lyubomirsky et al., 2006). Happiness is a feeling that has a general relationship with life's pleasure (Sharma and Malhotra, 2010), and those feelings that relate to happiness provide a mechanism for a happy life (Carver, 2003). Fordyce (1977) believes that the sense of happiness is the result of many good and bad experiences of life in the past and present. It can also be said that happiness relates to the mental and psychological state of man in terms of well-being and peace (Kahneman and Krueger, 2006). In general, the sense of happiness in each person's life is a fundamental requirement for individual development and also for the 
improvement and progress of social and economic conditions in a community (Gilbert, 2006).

With respect to happy city, social scholars believe that true happiness forms in big cities (Figure 1). Although no evidence has been put forward to support this theory, the joy of people living in the city as a clear and obvious truth is accepted by many scholars as a clear indication (Okulicz-Kozaryn, 2017). Living in cities has many advantages. For example, Skilled labor said that creativity in various fields and economics on the micro and macro scale are those that are far more likely to be formed in happy cities (O'Sullivan, 2009). Happiness in cities is a category that not only affects individual characteristics but also plays an important role in environmental elements in the city (National Research Council, 2002).

Apart from that among urban planners and designers, there is a widespread belief that the shape and form of buildings and cities can lead to significant changes in behaviour, sense of happiness and improved social interactions (Rapoport, 1997). From Montgomery's perspective, happy city is a city without carbon footprint that can protect the health of citizens (Samavati and Ranjbar, 2017). Regarding the structure and integrity of city, Montgomery suggests guidelines based on the views of philosophers, psychologists, economists and sociologists. Montgomery believes that in addition to addressing the basic needs of its citizens, such as the need for food, shelter and security, they should consider other aspects of their citizens' lives; Happy city should do its best for citizens to enjoy as much as possible and minimize their problems. Happy city not only should lead citizens to health more than the disease but also should be resistant to environmental and economic risks. It should act fairly in the division of public spaces, services, access, mobility, pleasure and costs. Most importantly, a happy city should be able to build strong relationships between friends, family and strangers that will actually make the city's life meaningful. Last but not least, a happy city should celebrate important and influential events that can persuade citizens into communication (Montgomery, 2013). In general, it can be pointed out that researches and experience at the global level show that physical stimuli in the built environment plays a key role in promoting the sense of happiness among citizens and creating a vibrant environment (White et al., 2013). Also, a happy city, in addition to investing in the basic needs of citizens, such as increased job opportunities and making public spaces, would emphasis in increasing the sense of participation, guaranteeing freedom of movement and flexible relocation and infrastructure design and increasing communication and interactions in urban areas (Wernick, 2008).

Table 2. Summary of the studies related to present study

\begin{tabular}{|c|c|c|c|c|}
\hline Study & Statement & Case Study & $\begin{array}{c}\text { Method and } \\
\text { Analysis }\end{array}$ & Findings \\
\hline & $\begin{array}{c}\text { Evaluation of the } \\
\text { relationship } \\
\text { between pollution } \\
\text { and reported } \\
\text { subjective well- } \\
\text { being (happiness) in }\end{array}$ & $\begin{array}{c}\text { Ten } \\
\text { European } \\
\text { countries }\end{array}$ & $\begin{array}{c}\text { Using a set } \\
\text { of panel } \\
\text { data from } \\
\text { happiness } \\
\text { surveys, } \\
\text { jointly with } \\
\text { data on } \\
\text { income and } \\
\text { air pollution }\end{array}$ & $\begin{array}{c}\text { The built environment } \\
\text { factors and } \\
\text { environmental problems } \\
\text { like air pollution play a } \\
\text { statistically significant } \\
\text { role as a predictor of } \\
\text { inter-country and inter- } \\
\text { temporal differences in } \\
\text { subjective well-being } \\
\text { (happiness) }\end{array}$ \\
\hline$\underline{\underline{(\text { White et }}}$ & $\begin{array}{c}\text { Explore the relation } \\
\text { between urban }\end{array}$ & $\begin{array}{c}\text { Data from } \\
\text { the British }\end{array}$ & $\begin{array}{c}\text { Using panel } \\
\text { data from }\end{array}$ & $\begin{array}{c}\text { People have both lower } \\
\text { mental distress and }\end{array}$ \\
\hline
\end{tabular}




\begin{tabular}{|c|c|c|c|c|}
\hline & $\begin{array}{l}\text { green space and } \\
\text { Happiness }\end{array}$ & $\begin{array}{l}\text { Household } \\
\text { Panel } \\
\text { Survey }\end{array}$ & $\begin{array}{l}\text { over } 10,000 \\
\text { individuals }\end{array}$ & $\begin{array}{l}\text { higher well-being when } \\
\text { living in urban areas with } \\
\text { more green space }\end{array}$ \\
\hline $\begin{array}{l}\text { Vinson } \\
\text { and } \\
\text { Ericson } \\
(\underline{2014})\end{array}$ & $\begin{array}{l}\text { Evaluation of the } \\
\text { social dimension of } \\
\text { happiness }\end{array}$ & $\begin{array}{l}\text { Cities in } \\
\text { Australia }\end{array}$ & $\begin{array}{l}\text { Questionnai } \\
\text { res and } \\
\text { statistical } \\
\text { analysis }\end{array}$ & $\begin{array}{l}\text { Education, marriage, } \\
\text { children, human rights } \\
\text { and, particularly in the } \\
\text { context of Australian } \\
\text { society, perceived choice } \\
\text { in life affect on } \\
\text { happiness. }\end{array}$ \\
\hline $\begin{array}{l}\text { Uchida } \\
\text { and } \\
\text { Ogihara } \\
(\underline{2012})\end{array}$ & $\begin{array}{l}\text { Identifying the } \\
\text { substantial cultural } \\
\text { differences in the } \\
\text { meaning of } \\
\text { happiness, } \\
\text { predictors of } \\
\text { happiness, and how } \\
\text { social changes are } \\
\text { related to happiness }\end{array}$ & $\begin{array}{l}\text { European- } \\
\text { American } \\
\text { and East } \\
\text { Asian } \\
\text { cultural } \\
\text { contexts }\end{array}$ & $\begin{array}{l}\text { Content } \\
\text { analysis } \\
\text { method }\end{array}$ & $\begin{array}{l}\text { In European -American } \\
\text { cultural contexts, } \\
\text { happiness is construed } \\
\text { as including experience } \\
\text { of a highly desirable and } \\
\text { positive emotional state. } \\
\text { In contrast, in } \\
\text { East Asian cultural } \\
\text { contexts } \\
\text { happiness is construed } \\
\text { as including experience } \\
\text { of both positive and } \\
\text { negative emotional state }\end{array}$ \\
\hline $\begin{array}{l}\text { Tiwari } \\
\text { and } \\
\text { Mutascu } \\
(\underline{2015)}\end{array}$ & $\begin{array}{l}\text { Investigation of the } \\
\text { relationship } \\
\text { between } \\
\text { environmental } \\
\text { degradation and } \\
\text { happiness }\end{array}$ & $\begin{array}{c}\text { In } 23 \\
\text { developed } \\
\text { contemporar } \\
\text { y economies }\end{array}$ & $\begin{array}{l}\text { The vector } \\
\text { autoregressi } \\
\text { on (VAR) } \\
\text { approach }\end{array}$ & $\begin{array}{l}\text { The joint influence of } \\
\text { GDP and environmental } \\
\text { degradation on happiness } \\
\text { is not significant. }\end{array}$ \\
\hline $\begin{array}{l}\text { Tiwari } \\
(\underline{2011)})\end{array}$ & $\begin{array}{l}\text { Identifying the } \\
\text { relationship } \\
\text { between the } \\
\text { happiness of people } \\
\text { and environmental } \\
\text { degradation }\end{array}$ & $\begin{array}{c}\text { Data from } \\
21 \\
\text { countries for } \\
\text { the period } \\
1970-2005\end{array}$ & $\begin{array}{l}\text { Statistical } \\
\text { analysis like } \\
\text { regression }\end{array}$ & $\begin{array}{l}\text { Environmental } \\
\text { degradation matters for } \\
\text { the happiness of the } \\
\text { people, and as } \\
\text { environmental } \\
\text { degradation increases, } \\
\text { their happiness decreases }\end{array}$ \\
\hline $\begin{array}{l}\text { Samavati } \\
\text { and } \\
\text { Ranjbar } \\
(\underline{2017})\end{array}$ & $\begin{array}{l}\text { Investigation of the } \\
\text { physical stimuli that } \\
\text { affect citizens' } \\
\text { happiness }\end{array}$ & $\begin{array}{l}\text { The } \\
\text { pedestrian } \\
\text { area of } \\
\text { central } \\
\text { Tehran, Iran }\end{array}$ & $\begin{array}{l}\text { Field } \\
\text { observation, } \\
\text { interview, } \\
\text { and a } \\
\text { conceptual } \\
\text { model }\end{array}$ & $\begin{array}{l}\text { The physical indicators, } \\
\text { including environmental } \\
\text { elements, pedestrian- } \\
\text { orientedness, bicycle- } \\
\text { orientedness, flexibility, } \\
\text { legibility, variety, and } \\
\text { place identity, affect } \\
\text { people's happiness. }\end{array}$ \\
\hline $\begin{array}{l}\text { Lenzen } \\
\text { and } \\
\text { Cummins } \\
(\underline{2013})\end{array}$ & $\begin{array}{l}\text { Evaluation of the } \\
\text { link between } \\
\text { environmental and } \\
\text { social indicators and } \\
\text { happiness }\end{array}$ & $\begin{array}{c}\text { A Case } \\
\text { Study of } \\
\text { Australian } \\
\text { Lifestyles }\end{array}$ & $\begin{array}{l}\text { Statistical } \\
\text { analysis like } \\
\text { Multivariate } \\
\text { Regressions }\end{array}$ & $\begin{array}{l}\text { Living together with } \\
\text { people is likely to create } \\
\text { a win-win situation where } \\
\text { both climate and } \\
\text { wellbeing benefit. }\end{array}$ \\
\hline$\frac{(\underline{\text { Okulicz- }}}{\text { Kozaryn, }}$ & $\begin{array}{l}\text { Evaluation of the } \\
\text { effect of size of a } \\
\text { place on happiness }\end{array}$ & $\begin{array}{l}\text { The US } \\
\text { megacities }\end{array}$ & $\begin{array}{c}\text { Statistical } \\
\text { analysis }\end{array}$ & $\begin{array}{l}\text { The big cities are too big: } \\
\text { the probability of being } \\
\text { unhappy increases } \\
\text { significantly when city } \\
\text { size exceeds hundreds of } \\
\text { thousands of people }\end{array}$ \\
\hline $\begin{array}{l}\text { Su et al. } \\
(\underline{2021})\end{array}$ & $\begin{array}{l}\text { Investigation of } \\
\text { The impact of } \\
\text { immediate urban } \\
\text { environments on } \\
\text { people's momentary } \\
\text { happiness }\end{array}$ & $\begin{array}{l}\text { Guangzhou, } \\
\text { China }\end{array}$ & $\begin{array}{l}\text { Ecological } \\
\text { momentary } \\
\text { assessment } \\
\text { (EMA) and } \\
\text { the day } \\
\text { reconstructi } \\
\text { on method } \\
\text { (DRM) }\end{array}$ & $\begin{array}{l}\text { Momentary happiness is } \\
\text { influenced by built } \\
\text { environment } \\
\text { characteristics, including } \\
\text { temperature, noise, } \\
\text { PM2.5, population, POI } \\
\text { density, POI types and } \\
\text { street intersections. }\end{array}$ \\
\hline
\end{tabular}


Overall, while there is some similarity among the concept of quality of life, life satisfaction, happy city, and healthy city (Kahneman et al., 1997), each of them has its unique way of making the place. Quality of life is defined as a wide concept that includes three meanings: quality of the living environment, quality of performance, and subjective enjoyment of life. However, the concept of happiness is considered as a part of the third category. It might be explained as the total appreciation of one's life as a whole. In the meantime, Daniel Gilbert (2006) believes that the meaning of happiness is a more transitory construct than life satisfaction. It means that life satisfaction is not only more stable than happiness, it is also broader in scope. Apart from that, quality of life is associated with living conditions like the amount and quality of food, the state of one's health, and the quality of one's shelter (Veenhoven, 1991). Turning to a healthy theme, which is strongly connected with livability, scholars believe that it is important to find out that why people living in some urban areas have a greater risk to have health problems (Sepe, 2018). These include disparities, crowding, noise, pollution, which can produce stress and persuade people to give away from social relationships; the low presence of green spaces, security, and privacy (McCay, 2017). It might be said that while the concept of a happy city emphasizes individual viewpoints regarding the quality of place, the concept of a healthy city works on the quality of physical dimension in urban areas to improve the quality of life (Figure 2).

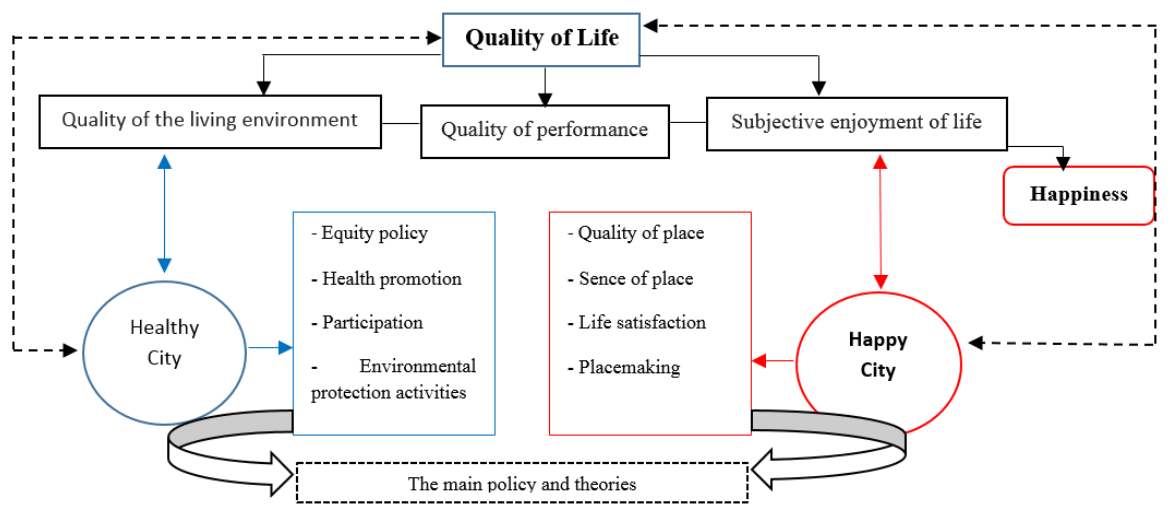

Figure 2. Key relationships among the concepts of quality of life, happy city and healthy city

\subsection{Mehr housing projects and happiness}

The main problem of the housing market in developing countries might generally be due to the rapid and constant urbanization that is the result of population growth. As a result, cities in developing countries are more likely to face affordable housing demand for urban low-income groups, as well as competition and quarrels for urban infrastructure (Golubchikov and Badyina, 2012). One of these types of housing is social housing, which mainly stems from social goals, and it is produced on the basis of acceptable standards, possibly lower prices than the standards of the housing pattern (Dallalpour, 2000). In different countries across the globe, including developing countries, there are various policies for housing, especially for low-income groups. In Iran, in recent years, in order to meet the legal and customary expectations of housing for low-income groups, the government has been implementing the Mehr housing policy (Poorjohari, 2010). Mehr housing project was one of the largest construction projects in Iran to provide affordable housing for low-income groups. The plan, aimed at providing 
housing for low-income groups starting in 2007, removes land prices from housing prices and provides residential customers with a 99-year tenancy (Nastaran and Ranaei, 2010; Nouri and Asadpour, 2015).

The eighth and ninth government's approach to housing was followed by policies like Zero of land, with laws such as the bill regulating and supporting the production and supply of housing, to executive solutions such as the Mehr housing plan (Ajilian et al., 2015; Ivani and Rostami, 2014). In the definition of this project, it can be said that the Mehr Housing project is a plan with the aim of reducing and eliminating the cost of land from the finished building cost, and it is designed to supply living places for lowincome and middle-income families (Etminani-Ghasrodashti et al.,2017; Kalhor et al.,2013; Poormohamadi et al., 2012). The officials also believed that the cost of housing would be lowered by removing land prices from the cost of building and highlighting the role of government, in addition to increasing the accountability of housing demand in the coming years (Parhizgar and Shahedi, 2010). The general objectives of the Mehr Housing project include: helping to provide housing for low-income groups, improving the quality and quantity of housing production and supply, reducing inequalities in affordable housing, refining the metropolitan environment and improving environmental standards, attracting small funds, preventing increasing the price of land and housing, and preventing the development of marginalization and promoting social justice (Khalili et al., 2014).

Social housing projects such as Mehr Housing projects may have been able to meet the needs of the housing market in terms of shelter concepts. However, considering the quality of social housing projects from residents' viewpoints can complement such projects and would be a step towards sustainability of these residential environments (Figure 3). This point has been considered by Richard Florida; he has examined the relationship between quality of place and happiness and addressed the role of place in determining the individual's successes and happiness (Figure 4).

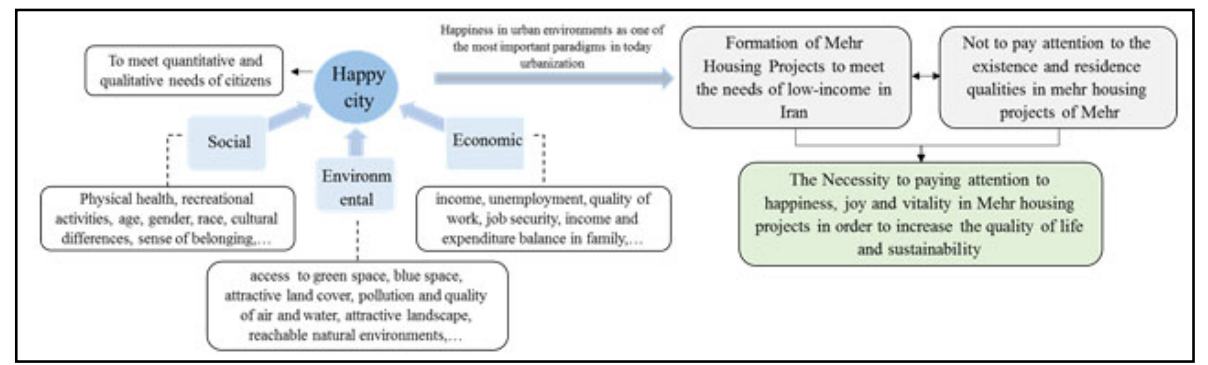

Figure 3. Principles of a happy city in Mehr housing projects

He believes that not only does the quality of place affect our happiness, but also the type of place in which we live is a key indicator for success. Florida defines the links between the sense of happiness and place. Firstly, he believes that place is a key point that is effective in creating the activity because this indicator allows individuals to do personal tasks and to be economically productive. Secondly, through personal feeling, we can adapt ourselves to a place and environment; the sense of belonging gives people something that they belong to places (Florida, 2002, 2008). In addition, the National Centre for Research also emphasizes that the relationship between happiness and place can be explained according to two concepts. The first one is happiness and scale; places have different scales from the home to the city. Different scales must be applied in designing to create a particular place 
or activity to promote happiness. The second one is that happiness and the dependency of place: happiness is a place-based concept, such as "consumption, production, and distribution in a particular location, and can affect neighbourhoods on a variety of scales"(National Research Council, 2013).

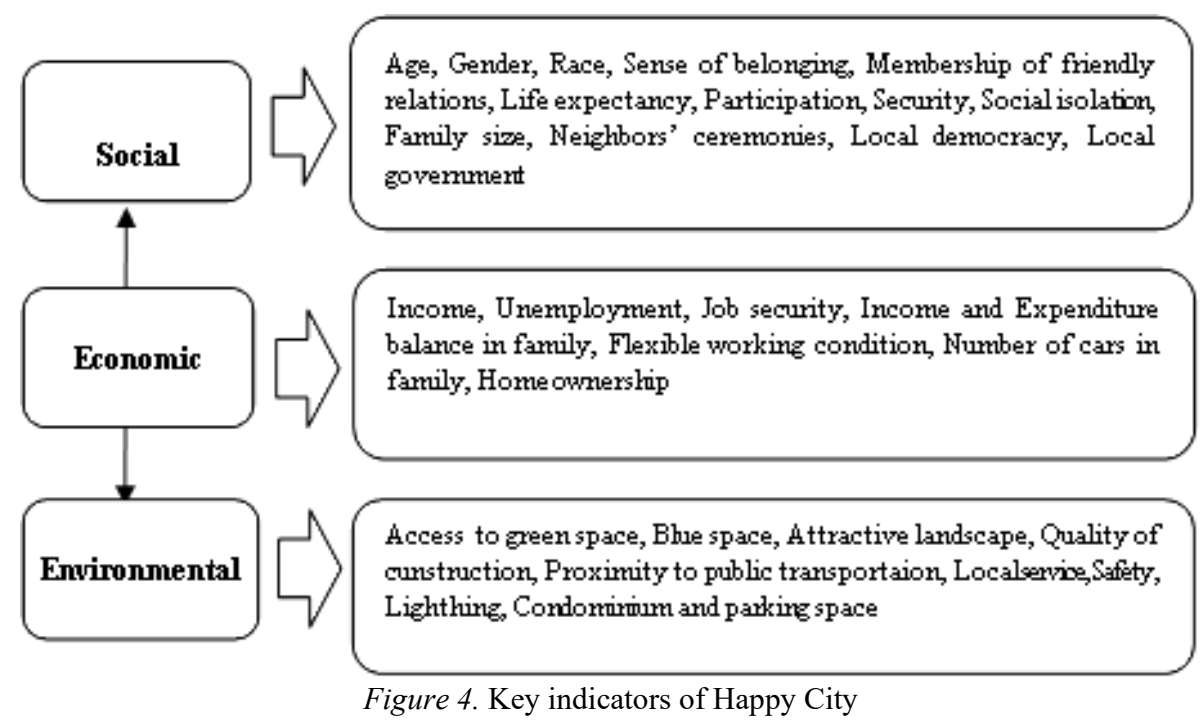

\section{METHODOLOGY}

\subsection{Case study}

The case study was selected from one of the phases of the Parand city. The new town of Parand is among the four new cities (beside Hashtgerd, Pardis and Andesh), which is located $33 \mathrm{~km}$ southwest of Tehran, on the important arteries such as Tehran-Saveh Road and Tehran Railroad (Figure 5). According to the comprehensive plan approved in 2006, the city of Parand has seven phases. The New Town of Parand is currently ranked first among 17 new Iranian cities due to the progress made in the construction of Mehr housing. With the largest number of Mehr residential units, Tehran Province (100,000 units) has been renamed to the capital of Mehr Housing (Naghsh Mohit engineering consultant, 2014). Phase 5 is one of the phases dedicated to the Mehr Housing Project in this city. The area of this phase is about 1433 hectares. In this phase, the Kozu Residential Complex, known as the Aftab town, which is the symbol of the city's Mehr housing, was selected as the case study. Aftab Town, with an area of 12.5419 hectares, is located southeast of Phase 5 of Parand new city; its position is shown in Fig. 1.3. According to the statistics of the construction of new cities company, 23,000 people live in 12900 residential units, which is the largest Mehr housing project in the city. 


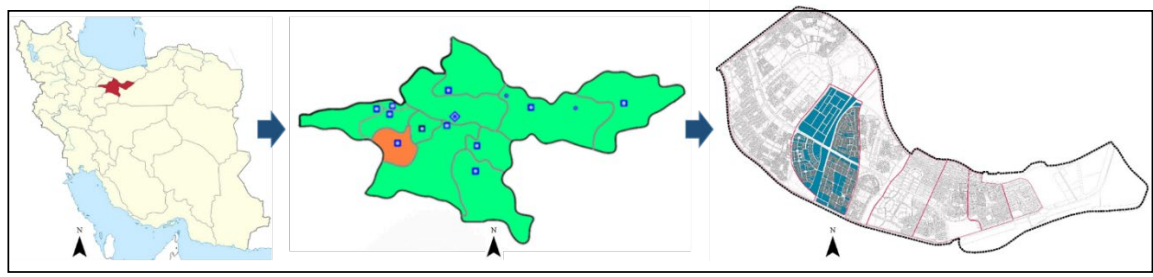

Figure 5. Location of case study

\subsection{Data analysis method}

The method used for this paper is descriptive-analytic (Figure 6). For collecting the data, document survey, field observation and survey (including household questionnaire) were used, and SPSS22 software was applied for data analysis. The statistical population of the research is households living in the city of Aftab (12900 residential units). The sample size was 373 based on the Cochran formula (with a 5\% error level and 95\% confidence level). Out of these distributed questionnaires, 362 questionnaires were analyzed based on the aggregation of responses to the questionnaires (not answering some of the questionnaire questions). The sampling method was a simple random method. Firstly, by numbering the residential units of the range, based on the numbers obtained, the number of questionnaires was distributed according to the parts.

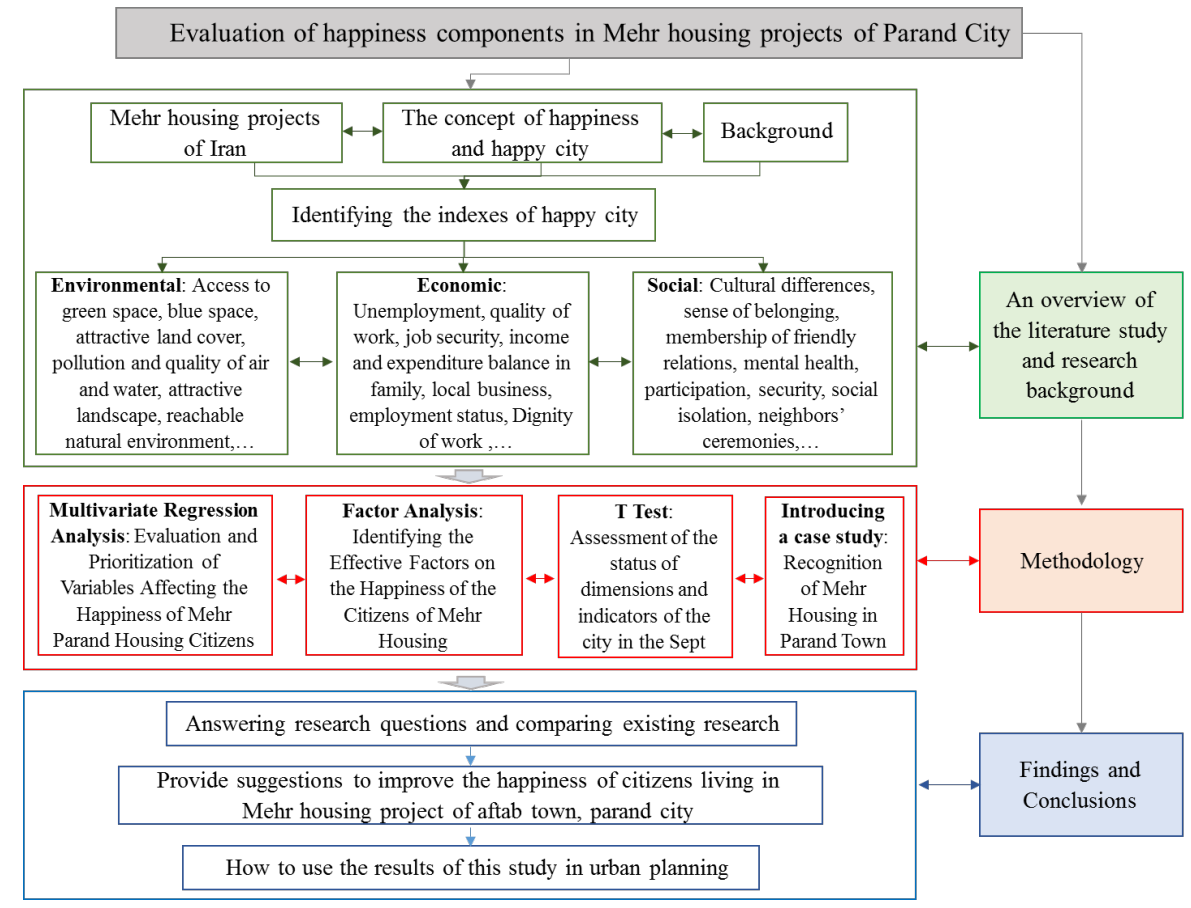

Figure 6 . The process of conducting research

The purpose of this study was to evaluate the indicators of the happy city in Mehr housing project of Aftab town of Parand city. Therefore, in order to move towards the aim of this study, the identified indicators in relation to the happy city in the form of a questionnaire were collected and distributed. The answers to the questions are based on the Likert spectrum (one: very low, two: low, three: average, four: high, five: very high). The validity and reliability of the questionnaire were evaluated based on expert opinion and using Cronbach's alpha coefficient in SPSS. This coefficient was calculated to be 0.922 , indicating the desirability of this work. Data analysis was 
performed based on different methods in SPSS22 software. In the following, a summary of descriptive information is provided in relation to respondents. Then, using the t-test, each of the indicators of the happy city identified in Table 1 was evaluated. In the next step, the factor analysis method was used to identify the main indicators of the city and its intermediate relationship. We used this method as a dimensionality-reduction method that is often applied to decrease the dimensionality of large data sets, as well as identifying the relationship among variables in other categories. This trend allowed us to have smaller data sets for analysis. And finally, the multivariate regression analysis method was used not only to prioritize the variables affecting happiness but also to find the relationship between happiness and independent variables, which would be identified in the previous steps.

\section{RESULTS AND DISCUSSION}

\subsection{General and personal characteristics of respondent questionnaires}

According to Table 2, men were more than women among respondents; as many as $67.7 \%$ of the respondents surveyed were men living in Mehr Homes. Also, most of the participants in the survey were between the ages of 35-65 (49.9\%) and had diplomas and associate degrees (53.6). 58 percent of those surveyed were unemployed, and most households in the range had a monthly income of \$200-300. 57.5 percent of households lived in rental houses. The per capita car share for each household in this poll is less than 0.5 , with $58 \%$ of households lacking personal cars. Generally speaking, the results of household income, the number of private households, the state of employment of the family, and the type of household ownership can indicate that the economic conditions are not appropriate for families in the ruling area. About $50 \%$ of the respondents were Fars, and more than $70 \%$ of the households had lived in Mehr housing for more than one year. The average household size in this research was 3.55 , of which $8.8 \%$ were low-income families (1-2 people), and $14.4 \%$ were relatively populated households (more than five people). In terms of life expectancy among residents, a significant percentage of residents $(21 \%)$ had a life expectancy of less than 50 years. Also, $43.9 \%$ of the people surveyed had a life expectancy of 51-75 years, and the rest had a life expectancy of over 75 years.

Table 2. A summary of the characteristics of respondents in the survey

\begin{tabular}{lllll}
\hline Characteristics & Modalities & Frequency & Present & Cumulative percent \\
\hline Sex & Female & 117 & 32.3 & 32.3 \\
Age & Male & 245 & 67.7 & 100 \\
& $\leq 17$ & 36 & 9.9 & 9.9 \\
& $18-35$ & 134 & 37.1 & 47 \\
Education & $35-65$ & 180 & 49.7 & 96.7 \\
background & $\geq 65$ & 12 & 3.3 & 100 \\
& Illiterate and Primary & 32 & 8.8 & 8.8 \\
& education & & & \\
Employment & Secondary education & 194 & 53.6 & 62.4 \\
status & Bachelor degree & 112 & 30.9 & 93.3 \\
Home & Master degree & 24 & 6.7 & 100 \\
& Working & 152 & 42 & 42 \\
& Not working & 209 & 58 & 100 \\
& Owner & 154 & 42.5 & 57.5
\end{tabular}




\begin{tabular}{lllll} 
ownership & Tenant & 208 & 57.5 & 100 \\
Length of & Less than 1 year & 99 & 27.5 & 27.5 \\
residency in & 1 years to 2 years & 144 & 39.7 & 67.2 \\
MHS buildings & More than 3 years & 119 & 32.8 & 100 \\
Ethnicity & Persian & 187 & 51.6 & 51.6 \\
& Non-Persian & 175 & 49.4 & 100 \\
Life expectancy & $\leq 50$ & 76 & 21 & 21 \\
& $51-75$ & 159 & 43.92 & 63.92 \\
& $\geq 75$ & 127 & 35.08 & 100 \\
Family size & $1-2$ & 32 & 8.8 & 8.8 \\
(Mean;3.55) & $3-4$ & 278 & 76.8 & 85.6 \\
& $\geq 5$ & 52 & 14.4 & 100 \\
Monthly & Bellows 200 \$ & 93 & 25.7 & 25.7 \\
income & $200-300 \$$ & 210 & 58 & 83.7 \\
& More than $300 \$$ & 59 & 16.3 & 100 \\
Number of cars & Without car & 210 & 58 & 58 \\
in the family & 1 & 148 & 41 & 99 \\
(Mean;0.48) & $\geq 2$ & 4 & 1 & 100 \\
\hline Ne: N-362 & & & &
\end{tabular}

Note: $\mathrm{N}=362$

\subsection{The evaluation of happy city indicators in the range}

In order to assess the status of the indicators of a happy city using residents' opinions, in this part of the study, a single-sample t-test was used. As shown in Table 3 and the Likert spectrum for the questionnaire (1: lowest and 5: highest), among the environmental indicators, the lighting quality has a more favourable position than other indicators. The average of this indicator is 3.65. Also, in this dimension, the quality of facilities and infrastructures is in a very unpredictable condition, and the average of this indicator has been evaluated in terms of residents (1.27).

Other undesirable indicators in this dimension are the access to public spaces and parking spaces (average: 2.29), access to public transportation (2.41) and safety level in the range (2.43), which have created an inappropriate environmental situation for residents. In connection with social dimension indicators, it can be said that the quality of service provided by the local government has a favourable relative position, with the average of this index 3.22 while other indicators are not suitable. Meanwhile, the indicators of the level of friendship among residents, the sense of belonging to the neighbourhood, the level of physical and psychological health, participation in charity, with averages $(1.89,2.21,2.41,2.43)$, created a very unpopular situation in the social dimension.

Among the effective economic indicators in happiness, the job security index had a relatively good status, and the average of this indicator in the residents' survey was 3.06. In this dimension, the job satisfaction index with an average of 1.76, the variation in price and type of housing, with a mean of 2.24 , and the proportion of the cost and household income, with an average of 2.54 , are in the end positions of this category. In general, in relation to the status of the indicators of a happy city in the range of Mehr housing, it can be said that according to the evaluation, the average of most indicators is considered of theoretical average (based on the Likert scale, a theoretical average of 2.5) And this indicates a general weakness in the status of the indicators of a happy city in a separate area. 
Table 3. T-test results of a single sample of happy city indicators in the site

\begin{tabular}{|c|c|c|c|c|}
\hline Dimensions & Index & $\mathrm{N}$ & Mean & Std. Deviation \\
\hline \multirow[t]{16}{*}{ Environmental } & $\begin{array}{l}\text { Quality of utility and } \\
\text { facilities }\end{array}$ & 362 & 1.27 & 1.384 \\
\hline & Quality of roads and streets & 362 & 2.80 & 1.299 \\
\hline & $\begin{array}{l}\text { Proximity to public } \\
\text { transportation }\end{array}$ & 362 & 2.41 & 1.111 \\
\hline & $\begin{array}{l}\text { Reachable natural } \\
\text { environments }\end{array}$ & 362 & 2.99 & 1.407 \\
\hline & Access to green space & 362 & 2.71 & 1.419 \\
\hline & Access to local service & 362 & 2.85 & 1.311 \\
\hline & Quality of blue space & 362 & 2.83 & 1.403 \\
\hline & $\begin{array}{l}\text { The suitable temperature in a } \\
\text { month }\end{array}$ & 362 & 3.02 & 1.348 \\
\hline & Average Annual Precipitation & 362 & 3.41 & 1.306 \\
\hline & $\begin{array}{l}\text { Quality of air and water in the } \\
\text { area }\end{array}$ & 362 & 2.09 & 1.347 \\
\hline & Attractive landscape & 362 & 2.77 & 1.416 \\
\hline & Quality of construction & 362 & 3.05 & 1.313 \\
\hline & Attractive land cover & 362 & 2.63 & 1.338 \\
\hline & $\begin{array}{l}\text { Access to Condominium and } \\
\text { parking spaces }\end{array}$ & 362 & 2.29 & 1.445 \\
\hline & $\begin{array}{l}\text { Level of Safety in } \\
\text { neighbourhood }\end{array}$ & 362 & 2.43 & 1.279 \\
\hline & Quality of lighting at night & 362 & 3.65 & 1.300 \\
\hline \multirow[t]{12}{*}{ Social } & $\begin{array}{l}\text { Level of Security in } \\
\text { neighbourhood }\end{array}$ & 360 & 2.32 & .911 \\
\hline & $\begin{array}{l}\text { Level of friendship between } \\
\text { neighbours (social isolation) }\end{array}$ & 362 & 1.89 & .934 \\
\hline & $\begin{array}{l}\text { Relationship with different } \\
\text { cultural groups }\end{array}$ & 362 & 2.58 & 1.266 \\
\hline & $\begin{array}{l}\text { Physical and mental health in } \\
\text { daily life }\end{array}$ & 362 & 2.41 & 1.291 \\
\hline & $\begin{array}{l}\text { Participate in charity } \\
\text { activities }\end{array}$ & 362 & 2.43 & 1.249 \\
\hline & $\begin{array}{l}\text { Attend the neighbours' } \\
\text { ceremonies }\end{array}$ & 362 & 2.58 & 1.055 \\
\hline & $\begin{array}{l}\text { Amount of recreational } \\
\text { activities in daily life }\end{array}$ & 362 & 2.76 & 1.299 \\
\hline & $\begin{array}{l}\text { Participation in solving the } \\
\text { problems related to the } \\
\text { housing area }\end{array}$ & 362 & 2.44 & 1.249 \\
\hline & $\begin{array}{l}\text { Participation in the meetings } \\
\text { related to the housing area }\end{array}$ & 362 & 2.62 & 1.135 \\
\hline & Quality of local democracy & 362 & 2.59 & 1.209 \\
\hline & $\begin{array}{l}\text { Sense of belonging to house, } \\
\text { neighbourhood }\end{array}$ & 362 & 2.21 & 1.219 \\
\hline & Quality of local government & 362 & 3.22 & 1.403 \\
\hline \multirow[t]{10}{*}{ Economic } & $\begin{array}{l}\text { Variety of type and cost of } \\
\text { House }\end{array}$ & 362 & 2.24 & 1.319 \\
\hline & Employee job security & 362 & 3.06 & 1.395 \\
\hline & Householder quality of work & 362 & 2.91 & 1.303 \\
\hline & Local business opportunity & 362 & 2.83 & 1.290 \\
\hline & Job opportunity & 362 & 2.83 & 1.056 \\
\hline & Doctor visit per year & 362 & 2.69 & 1.306 \\
\hline & $\begin{array}{l}\text { Income and expenditure } \\
\text { balance in family }\end{array}$ & 362 & 2.54 & 1.124 \\
\hline & Dignity of work & 362 & 1.76 & 1.035 \\
\hline & Flexible working condition & 362 & 2.67 & 1.200 \\
\hline & Number of working hours & 362 & 2.36 & 1.256 \\
\hline
\end{tabular}




\subsection{Identification of effective indicators on the residents' happiness}

In this part of the research, due to the high volume of the indicators of the happy city, the factor analysis method was used to identify the relationships between the indicators and summarize the number of factors as well as the explanation of a new structure among the indicators. The requirements for using the factor analysis method were controlled using Bartlett's CROILT test and the Kaiser-Meier-Olekin (KMO) standard (Table 4).

\begin{tabular}{lll} 
Table 4. KMO and Bartlett's Test & \\
\hline Kaiser-Meyer-Olkin Measure of Sampling Adequacy. & 855 \\
Bartlett's Test of Sphericity & Approx. Chi-Square & 6927.636 \\
& df & 703 \\
& Sig. & .000 \\
\hline
\end{tabular}

As indicated in Table 5, the sum of the cumulative variance of the six identified factors is $54.33 \%$, with the special value of all of these factors greater than one. The elongated factor table was used to identify the indicators of happiness in Mehr housing (Table 6). The first indicator, which accounts for $12.33 \%$ of the total variance, is referred to as the sense of happiness resulting from social relationships and work. The second indicator contributes $11.96 \%$ of the total variance. This indicator is called the spatial and physical association of the neighbourhood. The third indicator, which includes indicators for access to green space, access to local services, access to the natural environment, adequate lighting and safety levels within the scope, is named as the quality of local service, which allocated $8.65 \%$ of all variance to itself. The fourth indicator, called artificial and natural environment quality accounted for $8.38 \%$ of the total variance. The fifth indicator is $6.93 \%$ and the sixth indicator represents $6.40 \%$ of the total variance, which is named as the local government's support of the residents and the quality of the businesses, respectively.

Table 5. The total variance of happy city indicators (factor analysis)

\begin{tabular}{|c|c|c|c|c|c|c|c|c|c|}
\hline \multirow[t]{2}{*}{$\begin{array}{l}\text { Indica } \\
\text {-tors }\end{array}$} & \multicolumn{3}{|c|}{ Initial Eigenvalues } & \multicolumn{3}{|c|}{$\begin{array}{l}\text { Extraction Sums of } \\
\text { Squared Loadings }\end{array}$} & \multicolumn{3}{|c|}{$\begin{array}{l}\text { Rotation Sums of Squared } \\
\text { Loadings }\end{array}$} \\
\hline & Total & $\begin{array}{l}\% \text { of } \\
\text { variance }\end{array}$ & $\begin{array}{l}\text { Cumulat } \\
\text { ive } \\
\%\end{array}$ & Total & $\begin{array}{l}\% \text { of } \\
\text { varianc } \\
\mathrm{e}\end{array}$ & $\begin{array}{l}\text { Cumul } \\
\text { ative } \\
\%\end{array}$ & Total & $\begin{array}{l}\% \text { of } \\
\text { varian } \\
\text { ce }\end{array}$ & $\begin{array}{l}\text { Cumul } \\
\text { ative } \\
\%\end{array}$ \\
\hline 1 & 10.541 & 27.738 & 27.738 & 10.541 & 27.738 & 27.738 & 4.675 & 12.303 & 12.303 \\
\hline 2 & 2.804 & 7.379 & 35.118 & 2.804 & 7.379 & 35.118 & 4.415 & 11.619 & 23.922 \\
\hline 3 & 2.335 & 6.145 & 41.263 & 2.335 & 6.145 & 41.263 & 3.289 & 8.656 & 32.578 \\
\hline 4 & 2.099 & 5.523 & 46.786 & 2.099 & 5.523 & 46.786 & 3.187 & 8.387 & 40.965 \\
\hline 5 & 1.512 & 3.979 & 50.765 & 1.512 & 3.979 & 50.765 & 2.646 & 6.963 & 47.927 \\
\hline 6 & 1.356 & 3.569 & 54.333 & 1.356 & 3.569 & 54.333 & 2.434 & 6.406 & 54.333 \\
\hline Extracti & a Method & Principal C & aponent Ana & & & & & & \\
\hline
\end{tabular}

Table 6. The indicators extracted from factor analysis

\begin{tabular}{lccc}
\hline Extracted Indicator & Factor loadings & \% Variance & \% Cum \\
\hline \multicolumn{1}{c}{ Indicator 1 } & & & \\
$\begin{array}{l}\text { Access to Condominium and parking } \\
\text { spaces }\end{array}$ & 0.738 & 12.303 & 12.303 \\
$\begin{array}{l}\text { Level of friendship between } \\
\text { neighbours }\end{array}$ & 0.665 & & \\
\hline
\end{tabular}


Attend the neighbours' ceremonies

Participation in solving the problems related to the housing area

Variety of type and cost of House

Employment status

Flexible working condition

Indicator 2

Quality of roads and streets

0.554

Proximity to public transportation

0.610

Relationship with different cultural groups

Physical and mental health in daily life

Participate in charity activities

Sense of belonging to house, neighbourhood

\section{Indicator 3}

Access to green space

Access to local service

Reachable natural environments

Level of safety in the neighbourhood

Quality of lighting at night

\section{Indicator 4}

Quality of blue space

The suitable temperature in a month

Average Annual Precipitation

0.710

Attractive landscape

0.560

Quality of construction

0.618

Attractive land cover

\section{Indicator 5}

Amount of recreational activities in daily life

Quality of local democracy

Employment status

Number of working hours

Indicator 6

Householder quality of work

Local business opportunity

Job opportunity

0.882

0.804

0.504

609

.717

.596

0.608

0.554

0.609

0.612

0.474

Income and expenditure balance in
$11.619 \quad 23.922$

8.656

32.578

554

$6.963 \quad 47.927$

$8.387 \quad 40.965$ 
family

\subsection{Determining the effective indicators on the overall happiness of residents}

A multivariate regression method was used to evaluate and prioritize the identified variables. In fact, this method attempts to show how the general happiness of the inhabitants depends on the variables identified and the underlying variables (such as age, gender, etc.). The results show that among the variables, life expectancy, household size, monthly income, and education level are influential on the happiness of the inhabitants of Mehr housing. The variables of education and household size $(-0.100$ and -0.701 , respectively) have a negative effect on the happiness of residents living in Mehr housing project. This could indicate that those with high levels of education have a lower level of happiness. Also, people living in larger families feel less happy about living in Mehr housing. Life expectancy variables $(0.328)$ and monthly income $(0.132)$ have a positive effect on residents' happiness. In fact, people who have a higher life expectancy and higher monthly income feel happier than other people in the Mehr housing project. In relation to the indicators identified by factor analysis, the first indicator had no significant effect on the happiness of residents from living in Mehr houses, and other indicators had a positive effect on the happiness of the residents. Comparison of other indicators shows that the second indicator (0.438) had a greater impact on the residents' happiness in living in Mehr housing. Among the other indicators, indicator five (0.336), indicator six $(0.350)$, indicator three $(0.182)$ and the fourth indicator $(0.176)$ have priority in affecting the happiness of residents. Based on the findings, it can be said that the main and influential factors on the happiness of people living in Mehr housing are: quality of roads and streets, proximity to public transportation, relationship with different cultural groups, physical and mental health in daily life, participation in charity activities, and sense of belonging to house and neighbourhood.

Table 7. Output Multivariate Regression Analysis

\begin{tabular}{llllll}
\hline Variable & Beta & Std. Error & df & F & sig \\
\hline Sex & -0.018 & 0.151 & 1 & 0.115 & 0.734 \\
Age & 0.096 & 0.080 & 1 & 3.339 & 0.681 \\
Education background & -0.100 & 0.081 & 1 & 3.628 & .000 \\
Employment status & .008 & 0.159 & 1 & .020 & 0.887 \\
Home ownership & 0.006 & 0.151 & 1 & 0.12 & 0.915 \\
Length of residency in MHS & 0.093 & 0.088 & 1 & 3.111 & 0.079 \\
Ethnicity & 0.019 & 0.161 & 1 & 0.124 & 0.725 \\
Life expectancy & .328 & 0.094 & 1 & 1.517 & .000 \\
Family size & -0.701 & 0.101 & 1 & 1.84 & 0.019 \\
Monthly income & 0.132 & 0.085 & 1 & 6.41 & 0.012 \\
Indicator1 & -.012 & .056 & 1 & .054 & 0.816 \\
Indicator2 & 438 & .066 & 1 & 85.107 & .000 \\
Indicator3 & 182 & .073 & 1 & 12.257 & .000 \\
Indicator4 & .176 & .073 & 1 & 11.396 & .000 \\
Indicator5 & .336 & .070 & 1 & 45.699 & .000 \\
Indicator6 & .250 & .071 & 1 & 23.917 & .000 \\
\hline Model summary & $\mathrm{R}$ & $\mathrm{R}$ squares & Adjusted R squares & \\
\hline & 0.857 & 0.65 & 0.65 & & \\
\hline ANOVA analysis & Sum of & Mean & df & $\mathrm{F}$ & Sig. \\
& squares & squares & & & \\
\hline Regression & 316.136 & 18.596 & 17 & 16.530 & .000
\end{tabular}


\begin{tabular}{llll} 
Residual & 384.753 & 1.125 & 342 \\
\hline
\end{tabular}

$\begin{array}{lll}\text { Total } & 700.889 & 359\end{array}$

\section{CONCLUSION}

The present study sought to identify and evaluate the indicators of the city of happiness in affordable housing projects. The results show that happy city indicators are not achieved in the Mehr housing project. The case study used in this paper is a social housing project at a sub-city and neighbourhood scale. Similarities and differences of indicators in a different spatial and social context are to be determined by further research and in other cities.

As for the main question of this study, which emphasized the identification of the indicators that make up the city of happiness, six indicators were identified for this purpose. These indicators include the sense of happiness resulting from social and work relationships, the sense of joy and happiness resulting from the physical and spatial association of the neighbourhood, the quality of local service, the quality of the artistic and natural environment in the neighbourhood, the local government's support of local residents and the quality of the business environment. Among the identified variables that affect the happiness of the inhabitants of Mehr housing and the underlying variables, the evaluations showed that life expectancy and monthly income variables have a positive effect on happiness. Also, the variables of education and family size have a negative impact on happiness.

Regarding the present research approach, which emphasized the identification and evaluation of the indicators of happiness in Iran's Mehr Housing Project as an affordable housing project, it can be said that compared with the research carried out in this area, all dimensions of happiness in the community have been taken into account. The results of this study, compared with the results of the previous research, show that the outcomes of the present study are consistent with the results of the research by Vinson and Ericson (2014) on the effect of the level of education and income on the level of community happiness; by Hsu and Chang (2015), on the positive impact of social participation and social interactions on the happiness of people; by Brereton et al. (2008), on the effect of climate variables, healthy environment on happiness; by Welsch (2006) on the effect of air pollution on happiness; by White et al. (2013) on positive effects of neighbourhood and access to green spaces on happiness; and by Abounoori and Asgarizadeh (2013), on the negative impact of unemployment and inflation on happiness. However, the results of this study are not consistent with the results of the research by Gudmundsdottir (2013), one concerning the ineffectiveness of income and unemployment on happiness; and by Habibzadeh and Allahvirdiyani (2011), inefficiency, literacy, income, and marital status are not in line with happiness.

In addition, according to the outcomes, the most important indicator on the level of happiness of inhabitants is related to physical and spatial indicators. Based on the indexes that make up this indicator, the most important solutions for increasing the level of joy and happiness of the site of Mehr Housing project might be: organizing street and main roads in the area, organizing and improving pedestrians, organizing public transport stations, improving access to public transport, increasing transportation options such as bicycle paths and distinct pedestrians, increasing communication with other neighbourhoods of the city by organizing 
festivals and native festivals, strengthening communication with various cultural groups, increasing the opportunity for sports activities at the level of the range, improving access to green and open spaces, encouraging residents for increasing participation in charity and solving neighborhood problems, strengthening identity and sense of belonging in the range and paying attention to residents' perspectives on future design and planning.

Last but not least, the present study, from two perspectives, can have an essential application in urban planning. First of all, by identifying the indicators of a happy city, it can be used to improve the indicators of a happy city and increase the level of happiness and vitality in the community, which can be useful in the decision-making process. From another point of view, the results of the present study indicate that in order to solve issues related to the low-income households' homeownership, not only physical environment but also social-economic indicators should be taken into consideration. Hence, urban planners should have a comprehensive perspective to address the problems in affordable housing projects.

We acknowledge that our paper unavoidably has some limitations. The first limitation of the present study is related to the gathering of data by questionnaires. Around 2 percent of the questionnaires were not completed and returned, which might raise the issue of response bias. Besides, data for measuring the quality of public facilities in some cases, which is important for happiness, were omitted due to the lack of response. Besides, the survey used in the paper was conducted in the middle of 2020, and it might fail to present the latest change of the indexes that affect residents' happiness. Secondly, due to the close relationship between life satisfaction, and happiness, there were interpretation limitations for finding the appropriate indexes. Also, the omission of indexes relate to their coverage in the literature should be considered. And, finally, the proposed methodology presented in this paper can be improved. For example, a few case studies from other cities can be selected for more investigations, or, because of sorting and unobserved indicators, the observed relationships cannot be confidently interpreted as causal, which should be further studied in the future. For example, in order to have a better understanding of peoples' happiness in affordable housing projects, a few case studies from other kinds of affordable housing projects should be selected, and F'ANP as a new and comprehensive method for analyzing and prioritizing the indicators can be applied.

\section{REFERENCES}

Abounoori, E., \& Asgarizadeh, D. (2013). "Macroeconomic Factors Affecting Happiness". International Journal of Business and Development Studies, 5(1), 5-22.

Ajilian, S., Rafieian, M., \& Ahgasafari, A. (2015). "Principles, Dimensions and Residential Satisfaction Variables in Mehr Housing Planning, Case Study: Mehregan Township [In Persian]". Quarterly Journal of Urban Studies, 5(19), 27-36.

Akhundi, A., Berkpoor, N., Khalili, A., Sedaghatnia, S., \& Safi Yari, R. (2014). "Measurement of Urban Quality of Life in Tehran Metropolitan Area [In Persian]". Journal of Arts Fine, 14(19), 65-76.

Alesina, A., Di Tella, R., \& MacCulloch, R. (2001). Inequality and Happiness, MA02138, National Bureau of Economic Research, Cambridge.

Amorim, S. M., França, L. H. de F. P., \& Valentini, F. (2017). "Predictors of Happiness among Retired from Urban and Rural Areas in Brazil”. Psicologia: Reflexão e Crítica, 30(1), 2. doi: https://doi.org/10.1186/s41155-016-0055-3.

Anic, P., \& Toncic, M. (2013). "Orientation to Happiness, Subjective Well-Being and Life Goals". Psychological Topics, 22(1), 135-153. 
Argyle, M., \& Lu, L. (1990). "Happiness and Social Skills". Personality and Individual Differences, 11(12), 1255-1261. doi: https://doi.org/10.1016/0191-8869(90)90152-H.

Athota, V. S. (2013). "At The Role of Moral Emotions in Happiness". The Journal of Happiness \& Well-Being, 1(2), 115-120.

Atlas, J., \& Dreier, P. (1992). "From Projects to Communities: How to Redeem Public Housing". The American Prospect, 10, 74-85.

Ballas, D. (2013). "What Makes a 'Happy City'?". Cities, 32, 39-50. doi: https://doi.org/10.1016/j.cities.2013.04.009.

Ballas, D., \& Dorling, D. (2007). "Measuring the Impact of Major Life Events upon Happiness". International Journal of Epidemiology, 36(6), 1244-1252. doi: https://doi.org/10.1093/ije/dym182.

Ballas, D., \& Dorling, D. (2013). "The Geography of Happiness". In S. David, I. Boniwell, and A. C. Ayers (Eds.), The oxford handbook of happiness (465-481). Oxford University Press.

Balogun, A. (2014). "Dispositional Factors, Perceived Social Support and Happiness among Prison Inmates in Nigeria: A New Look". The Journal of Happiness \& Well-Being, 2(1), 16-33.

Bauman, J. F. (1987). Public Housing, Race, and Renewal Urban Planning in Philadelphia. Philadelphia: Temple University Press.

Bókony, V., Seress, G., Nagy, S., Lendvai, Á. Z., \& Liker, A. (2012). "Multiple Indices of Body Condition Reveal No Negative Effect of Urbanization in Adult House Sparrows". Landscape and Urban Planning, 104(1), 75-84. doi: https://doi.org/10.1016/j.landurbplan.2011.10.006.

Brereton, F., Clinch, J. P., \& Ferreira, S. (2008). "Happiness, Geography and the Environment”. Ecological Economics, 65(2), 386-396. doi: https://doi.org/10.1016/j.ecolecon.2007.07.008.

Buss, D. M. (2000). "The Evolution of Happiness". American Psychologist, 55(1), 15-23.

Carver, C. (2003). "Pleasure as a Sign You Can Attend to Something Else: Placing Positive Feelings within a General Model of Affect". Cognition and Emotion, 17(2), 241-261. doi: https://doi.org/10.1080/02699930302294.

Coles, N. A., Sims, V. K., \& Chin, M. G. (2015). "Lay Beliefs and Projections of Trait Happiness". The Journal of Happiness \& Well-Being, 3(2), 116-125.

Dallalpour, M. R. (2000). House Planning [In Persian]. Samt publication.

Danaei, A., Shariatpanahi, M., \& Mahdavi, M. (2016). "Analysis of the Role of Quality of Life Indicators in Rural Sustainable Development (Case Study: Kohgiluyeh and Boyerahmad Province, Bahmayi Tropical Region) [In Persian]”. Sarzamin Geographical Quarterly, 14(53), 71-92.

Delle Fave, A. (2013). "The Exploration of Happiness: Present and Future Perspectives". In Delle Fave, A. (Eds.), The Exploration of Happiness (pp.3-14). Dordrecht: Springer.

Diener, E., Lucas, R. E., Schimmack, U., \& Helliwell, J. F. (2009). Well-Being for Public Policy. New York: Oxford University Press.

Diener, E., Oishi, S., \& Lucas, R. E. (2003). "Personality, Culture, and Subjective WellBeing: Emotional and Cognitive Evaluations of Life". Annual Review of Psychology, 54(1), 403-425. doi: https://doi.org/10.1146/annurev.psych.54.101601.145056.

Diener, E., \& Seligman, M. E. P. (2004). "Beyond Money: Toward an Economy of WellBeing". Psychological Science in the Public Interest, 5(1), 1-31. doi: https://doi.org/10.1111/j.0963-7214.2004.00501001.x.

Dolan, P., Peasgood, T., \& White, M. (2008). "Do We Really Know What Makes Us Happy? A Review of the Economic Literature on the Factors Associated with Subjective WellBeing”. Journal of Economic Psychology, 29(1), 94-122. doi: https://doi.org/10.1016/j.joep.2007.09.001.

Engelbrecht, H.-J. (2009). "Natural Capital, Subjective Well-Being, and the New Welfare Economics of Sustainability: Some Evidence from Cross-Country Regressions". Ecological Economics, 69(2), 380-388. https://doi.org/10.1016/j.ecolecon.2009.08.011

Epley, D. R., \& Menon, M. (2008). "A Method of Assembling Cross-Sectional Indicators into a Community Quality of Life". Social Indicators Research, 88(2), 281-296. doi: https://doi.org/10.1007/s11205-007-9190-7.

Etminani-Ghasrodashti, R., Majedi, H., \& Paydar, M. (2017). “Assessment of Residential Satisfaction in Mehr Housing Scheme: A Case Study of Sadra New Town, Iran". Housing, Theory and Society, 34(3), 323-342. doi: https://doi.org/10.1080/14036096.2017.1298536.

Ferreira, S., \& Moro, M. (2010). "On the Use of Subjective Well-Being Data for Environmental Valuation". Environmental and Resource Economics, 46(3), 249-273. doi: https://doi.org/10.1007/s10640-009-9339-8. 
Ferrer-i-Carbonell, A., \& Gowdy, J. M. (2007). "Environmental Degradation and Happiness". Ecological Economics, 60(3), 509-516. https://doi.org/10.1016/i.ecolecon.2005.12.005.

Florida, R. (2002). The Rise of the Creative Class. Basic Books.

Florida, R. (2008). Who's Your City?. Basic Books.

Fordyce, M. W. (1977). "Development of a Program to Increase Personal Happiness". Journal of Counselling Psychology, 24(6), 511-521.

Frey, B. S. (2008). Happiness: A Revolution in Economics. MIT Press.

Frey, B. S., \& Stutzer, A. (2002). "The Economics of Happiness". World Economics, 3(1), 117.

Frijters, P., \& Van Praag, B. M. S. (1998). "The Effects of Climate on Welfare and Well-Being in Russia". Climatic Change, 39(1), 61-81. doi: https://doi.org/10.1023/A:1005347721963.

Gilbert, D. (2006). Stumbling on Happiness. London: Harper.

Golubchikov, O., \& Badyina, A. (2012). "Sustainable Housing for Sustainable Cities: A Policy Framework for Developing Countries". UN-HABITAT.

Gowdy, J. (2005). "Toward a New Welfare Economics for Sustainability". Ecological Economics, 53(2), 211-222. doi: https://doi.org/10.1016/j.ecolecon.2004.08.007.

Gu, L., Rosenberg, M. W., \& Zeng, J. (2017). "Competing Forces of Socioeconomic Development and Environmental Degradation on Health and Happiness for Different Income Groups in China". International Journal of Health Services, 47(4), 752-777. doi: https://doi.org/10.1177/0020731417725470.

Gudmundsdottir, D. G. (2013). "The Impact of Economic Crisis on Happiness". Social Indicators Research, 110(3), 1083-1101. doi: https://doi.org/10.1007/s11205-011-9973-8.

Habibzadeh, S., \& Allahvirdiyani, K. (2011). "Effects of Economic and Non Economic Factors on Happiness on Primary School Teachers and Urmia University Professors". Procedia - Social and Behavioral Sciences, 30, 2050-2051. doi: https://doi.org/10.1016/i.sbspro.2011.10.397.

Hall, P., \& Pfeiffer, U. (2000). Urban Future 21: A Global Agenda for Twenty-First Century Cities. Taylor \& Francis.

Hemati, M. (2006). "Studying Weakness and Strengthens Points of Maskan-e-Mehr Project and Presenting Complete Suggestions [In Persian]". Tehran: Housing Policymaking Group.

Hsu, H.-C., \& Chang, W.-C. (2015). "Social Connections and Happiness among the Elder Population of Taiwan". Aging \& Mental Health, 19(12), 1131-1137. doi: https://doi.org/10.1080/13607863.2015.1004160.

Isalou, A. A., Litman, T., Irandoost, K., \& Shahmoradi, B. (2015). "Evaluation of the Affordability Level of State-Sector Housing Built in Iran: Case Study of the Maskan-eMehr Project in Zanjan City”. Journal of Urban Planning and Development, 141(4).

Israel, D., \& Levinson, A. (2003). "Examining the Relationship between Household Satisfaction and Pollution". Paper to be Presented at Eastern Economics Association Meetings.

Ivani, H., \& Rostami, M. (2014). "Analysis the Opportunities and Threats of Mehr Housing in Mashhad Metropolis (A Case of Golbahar New Town)". American Journal of Engineering Research (AJER), 3(12), 1-6.

Kahneman, D., \& Krueger, A. B. (2006). "Developments in the Measurement of Subjective Well-Being". Journal of Economic Perspectives, 20(1), 3-24. doi: https://doi.org/10.1257/089533006776526030.

Kahneman, D., Wakker, P. P., \& Sarin, R. (1997). "Back to Bentham? Explorations of Experienced Utility". The Quarterly Journal of Economics, 112(2), 375-406. doi: https://doi.org/10.1162/003355397555235.

Kalhor, M. A., Esmailpour, H., \& Ahmadi, F. (2013). "Evaluation the Performance of the Mehr Housing Project in Iran (Case Study Saqez City)". Middle-East Journal of Scientific Research, 15(5), 707-711.

Kellert, S. R., \& Wilson, E. O. (1993). The Biophilia Hypothesis. Washington, DC: Island Press.

Kent, J. L., Ma, L., \& Mulley, C. (2017). "The Objective and Perceived Built Environment: What Matters for Happiness?”. Cities \& Health, 1(1), 59-71. doi: https://doi.org/10.1080/23748834.2017.1371456.

Khalili, A., Nurolahi, H., Rashidi, N., \& Rahmani, M. (2014). "Evaluation of Mehr Housing Policies in Iran and the Way to Improve It [In Persian]". Journal of Urban Studies, 4(13), 83-92.

King, K. A., Vidourek, R. A., Merianous, A., \& Singh, M. (2014). "A Study of Stress, Social Support, and Perceived Happiness among College Students". The Journal of Happiness \& Well-Being, 2(2), 132-144.

Lane, T. (2017). "How Does Happiness Relate to Economic Behaviour? A Review of the 
Literature". Journal of Behavioral and Experimental Economics, 68, 62-78. doi: https://doi.org/10.1016/j.socec.2017.04.001.

Lenzen, M., \& Cummins, R. A. (2013). "Happiness versus the Environment-A Case Study of Australian Lifestyles". Challenges, 4(1), 56-74.

Lyubomirsky, S., Tkach, C., \& DiMatteo, M. R. (2006). "What Are the Differences between Happiness and Self-Esteem". Social Indicators Research, 78(3), 363-404. doi: https://doi.org/10.1007/s11205-005-0213-y.

MacKerron, G., \& Mourato, S. (2009). "Life Satisfaction and Air Quality in London". Ecological $\quad$ Economics, 68(5), 1441-1453. https://doi.org/10.1016/j.ecolecon.2008.10.004.

Maddison, D., \& Rehdanz, K. (2011). "The Impact of Climate on Life Satisfaction". Ecological $\quad$ Economics, 70(12), 2437-2445. doi: https://doi.org/10.1016/i.ecolecon.2011.07.027.

Majeed, M. T., \& Mumtaz, S. (2017). "Happiness and Environmental Degradation: A Global Analysis". Pakistan Journal of Commerce and Social Sciences, 11(3), 753-772.

Marans, R. W., \& Stimson, R. J., eds. (2011). Investigating Quality of Urban Life: Theory, Methods, and Empirical Research. Dordrecht: Springer.

McCay, L. (2017). "Designing Mental Health into Cities”. Urban Design Group Journal, 142, 25-27.

Milligan, C., Gatrell, A., \& Bingley, A. (2004). “Cultivating Health': Therapeutic Landscapes and Older People in Northern England". Social Science \& Medicine, 58(9), 1781-1793. doi: https://doi.org/10.1016/S0277-9536(03)00397-6.

Mirzan, H., Bahreini, A., Moeinaddini, M., Asadi-Shekari, Z., Shah, M. Z., \& Sultan, Z. (2016). "Identify Significant Indicators for a Happy City". Planning Malaysia, 14(4), 263 272.

Montgomery, C. (2013). Happy City: Transforming Our Lives through Urban Design. Macmillan.

Morawetz, D., Atia, E., Bin-Nun, G., Felous, L., Gariplerden, Y., Harris, E., Soustiel, S., Tombros, G., \& Zarfaty, Y. (1977). "Income Distribution and Self-Rated Happiness: Some Empirical Evidence". The Economic Journal, 87(347), 511-522. doi: https://doi.org/10.2307/2231556.

Moro, M., Brereton, F., Ferreira, S., \& Clinch, J. P. (2008). "Ranking Quality of Life Using Subjective Well-Being Data". Ecological Economics, 65(3),448-460. doi: https://doi.org/10.1016/i.ecolecon.2008.01.003.

Musa, H. D., Yacob, M. R., Abdullah, A. M., \& Ishak, M. Y. (2018). "Enhancing Subjective Well-Being through Strategic Urban Planning: Development and Application of Community Happiness Index". Sustainable Cities and Society, 38,184-194. doi: https://doi.org/10.1016/j.scs.2017.12.030.

Myers, D. G., \& Diener, E. (1995). “Who Is Happy?”. Psychological Science, 6(1),10-19. doi: https://doi.org/10.1111/j.1467-9280.1995.tb00298.x.

Naghsh Mohit engineering consultant. (2014). "Transmission Review of Parand Master Plan, Iran Super Council of Architect and Urbanism [In Persian]".

Nastaran, M., \& Ranaei, A. (2010). "An Analysis on the Participation and Coworking in Preparing Lands Projects of Mehr Housing [In Persian]". Armanshahr Journal, 3(4), 111123.

National Research Council. (2002). Neem: A Tree for Solving Global Problems. The Minerva Group, Inc.

National Research Council. (2013). Subjective Well-Being Measuring Happiness, Suffering, and Other Dimensions of Experience. Washington, DC: The National Academies Press.

Ng, Y.-K. (2008). "Environmentally Responsible Happy Nation Index: Towards an Internationally Acceptable National Success Indicator". Social Indicators Research, 85(3), 425-446. doi: https://doi.org/10.1007/s11205-007-9135-1.

Nouri, M., \& Asadpour, K. (2015). "The Explanation of the Factors Affecting the Satisfaction of Residents of Mehr Housing from the Situation of Residence (Case Study: City of Dehaqan) [In Persian]". Journal of Urban Studies, 5(18), 63-76.

O’Sullivan, A. (2009). Urban Economics. McGraw-Hill.

Okulicz-Kozaryn, A. (2017). "Unhappy Metropolis (When American City Is Too Big)”. Cities, 61, 144-155. doi: https://doi.org/10.1016/j.cities.2016.04.011.

Pakzad, J. (2009). Series of Thoughts in Urbanization, Shahidi Publishing House, Tehran [In Persian].

Parhizgar, A., \& Shahedi, N. (2010). "A Review on Mehr Housing Project in Cities with Less than 25000 Population [In Persian]". Abadi Journal, 17(55), 44-69.

Poorjohari, A. (2010). "Mehr Housing, City or Impose Broad Unscheduled Grows with It [In Persian]". Abadi Journal, 69,14-18. 
Poormohamadi, M., Sadremoosavi, M., \& Abedini, A. (2012). “An Analysis of Government Housing Policies with an Emphasis on Economic Development, Social and Cultural [In Persian]". Journal of Urban Studies, 1(3), 34-43.

Rafieian, M., Ghazaie, M., \& Ghazi, R. (2018). "Study of Socio-Spatial Separation of Immigrants in Mashhad [In Persian]". Journal of Social Studies and Research in Iran, 7(1).

Rapoport, A. (1997). Human Aspects of Urban Form: Towards a Man-Environment Approach to Urban Form and Design. Pergamon Press.

Rehdanz, K., \& Maddison, D. (2005). "Climate and Happiness". Ecological Economics, 52(1), 111-125. doi: https://doi.org/10.1016/j.ecolecon.2004.06.015.

Samavati, S., \& Ranjbar, E. (2017). "The Effect of Physical Stimuli on Citizens' Happiness in Urban Environments: The Case of the Pedestrian Area of the Historical Part of Tehran". Journal of Urban Design and Mental Health, 2(2).

Savageau, D. (2007). Places Rated Almanac. Washington, DC: Places Rated Books LLC.

Searns, R. M. (1995). "The Evolution of Greenways as an Adaptive Urban Landscape Form". Landscape and Urban Planning, 33(1), 65-80. doi: https://doi.org/10.1016/01692046(94)02014-7.

Sepe, M. (2018). "Liveable and Healthy City Design". In G. Passerini and N. Marchettini (Eds.), Sustainable development and planning X (pp. 177-189). UK: WIT Press.

Sharma, A., \& Malhotra, D. (2010). "Socio-Psychological Correlates of Happiness in Adolescents". European Journal of Social Sciences, 12(4), 651-662.

Shochat, E., Warren, P. S., Faeth, S. H., McIntyre, N. E., \& Hope, D. (2006). "From Patterns to Emerging Processes in Mechanistic Urban Ecology". Trends in Ecology \& Evolution, 21(4), 186-191. doi: https://doi.org/10.1016/j.tree.2005.11.019.

Su, L., Zhou, S., Kwan, M.-P., Chai, Y., \& Zhang, X. (2021). "The Impact of Immediate Urban Environments on People's Momentary Happiness". Urban Studies, 0042098020986499. doi: https://doi.org/10.1177/0042098020986499.

Suhaida, M. S., Tawil, N. M., Hamzah, N., Che-Ani, A. I., \& Tahir, M. M. (2010). "A Conceptual Overview of Housing Affordability in Selangor, Malaysia". International Journal of Architectural and Environmental Engineering, 4(12), 2289-2291.

Tanguay, G., Rajaonson, J., Lefebver, J. F., \& Lanoie, P. (2009). "Measuring the Sustainability of Cities: A Survey-Based Analysis of the Use of Local Indicators". CIRANO - Scientific Publications, 2009s-02.

Thalmann, P. (2003). “'House Poor' or Simply 'Poor'?”. Journal of Housing Economics, 12(4), 291-317. doi: https://doi.org/10.1016/j.jhe.2003.09.004.

Tiwari, A. K. (2011). "Happiness and Environmental Degradation: What Determines Happiness?". Economics Bulletin, 31(4), 3192-3210.

Tiwari, A. K., \& Mutascu, M. (2015). "The Relationship between Environmental Degradation and Happiness in 23 Developed Contemporary Economies". Management of Environmental Quality: An International Journal, 26(2), 301-321. doi: https://doi.org/10.1108/MEQ-05-2014-0077.

Turkoglu, H. (2015). "Sustainable Development and Quality of Urban Life”. Procedia - Social and Behavioral Sciences, 202, 10-14. doi: https://doi.org/10.1016/j.sbspro.2015.08.203.

Uchida, Y., \& Ogihara, Y. (2012). "Personal or Interpersonal Construal of Happiness: A Cultural Psychological Perspective. International Journal of Wellbeing”. International Journal of Wellbeing, 2(4), 354-369.

Ulrich, R. S. (1984). "View through a Window May Influence Recovery from Surgery", Science, 224(4647), 420-421. doi: https://doi.org/10.1126/science.6143402.

United States. (1937). "United States Housing Act of 1937". 50(Part 1).

Veenhoven, R. (1991). “Is Happiness Relative?”. Social Indicators Research, 24(1), 1-34. doi: https://doi.org/10.1007/BF00292648.

Vemuri, A. W., \& Costanza, R. (2006). "The Role of Human, Social, Built, and Natural Capital in Explaining Life Satisfaction at the Country Level: Toward a National WellBeing Index (NWI)". Ecological Economics, 58(1), 119-133. doi: https://doi.org/10.1016/j.ecolecon.2005.02.008

Vinson, T., \& Ericson, M. (2014). "The Social Dimensions of Happiness and Life Satisfaction of Australians: Evidence from the World Values Survey". International Journal of Social Welfare, 23(3), 240-253.

Vuluku, G., \& Gachanja, J. (2014). "Supply Side Aspects of Residential Housing for Low Income Earners in Kenya”. Research in Applied Economics, 6(3), 271-286.

Welsch, H. (2006). "Environment and Happiness: Valuation of Air Pollution Using Life Satisfaction Data". Ecological Economics, 58(4), 801-813. doi: https://doi.org/10.1016/j.ecolecon.2005.09.006.

Welsch, H. (2009). "Implications of Happiness Research for Environmental Economics". Ecological Economics, 68(11), 2735-2742. doi 
https://doi.org/10.1016/j.ecolecon.2009.06.003.

Welsch, H., \& Kuhling, J. (2009). "Using Happiness Data for Environmental Valuation: Issues and Applications". Journal of Economic Surveys, 23(2), 385-406.

Welsch, H., \& Kuhling, J. (2016). "Affective States and the Notion of Happiness". The Journal of Happiness \& Well-Being, 4(1), 101-114.

Wernick, J. (2008). Building Happiness. Architecture to Make You Smile. London: Black Dog.

White, M. P., Alcock, I., Wheeler, B. W., \& Depledge, M. H. (2013). "Would You Be Happier Living in a Greener Urban Area? A Fixed-Effects Analysis of Panel Data". Psychological Science, 24(6), 920-928. doi: https://doi.org/10.1177/0956797612464659.

Wren, S. (2016). Happy City Index 2016 Report. UK: Happy City Measurement \& Policy Team.

Yan, S., Ge, X. J., \& Wu, Q. (2014). "Government Intervention in Land Market and Its Impacts on Land Supply and New Housing Supply: Evidence from Major Chinese Markets". Habitat International, 44, 517-527. doi: https://doi.org/10.1016/j.habitatint.2014.10.009.

Zidanšek, A. (2007). "Sustainable Development and Happiness in Nations". Energy, 32(6), 891-897. doi: https://doi.org/10.1016/j.energy.2006.09.016. 